\title{
STUDI EKOLOGI OSEANOGRAFI TELUK MANADO UNTUK PENENTUAN STRUKTUR ARTIFICIAL CORAL GARDEN DAN AREA MANGROVE SEBAGAI DESTINASI WISATA BARU
}

(Study of Oceanography Ecological Manado Bay for Determine the Structure of Artificial Coral Garden and Mangrove Area as a New Tourist Destination)

\author{
Oktavianus Lintong, Dannie R.S. Oroh ${ }^{\star}$ dan Easter. Ch. M. Tulung \\ Program Studi Ekowisata Bawah Laut Jurusan Pariwisata Politeknik Negeri Manado
}

*Corresponding author: dannieorohpolimdo@gmail.com

\begin{abstract}
The purpose of this study is to investigate the ecological conditions of mangrove ecosystems in the Manado Bay and analyze the suitability of the mangrove ecosystems as a new tourist destination, examine the oceanographic conditions in the Manado Bay area, study the data on the development of coral reef ecosystems to be able to produce artificial coral reefs and produce mangrove areas and coral reefs artificial as a new tourist destination. This research was conducted in April - September 2019 with the location of Manado Bay and the location of the Manado Bay coral reef ecosystem survey set at 3 sample points, equipped with 3 points in front of the BOBOCA Malalayang monument, in front of the Malalayang gas station and ANTRA Sario. Retrieval of coral reef data is by using the Line Intercept Transect (LIT) method. LIT observations were carried out with SCUBA diving at a depth of $6 \mathrm{~m}$. Observations were made by recording coral lifeforms found along the transect line, and calculating the percentage of the selection. The data taken is the percentage of dead coral cover, live coral, and type of life form, diversity index taken at 3 sample points. From field observations found on Site 2 (Front of Malalayang gas station) the condition of coral reefs is included in the good category, with the percentage of live coral cover (Hard Coral) of $55 \%$. At this station found various types of coral growth, but the highest at this station is a form of growth of Coral Masive (CM) of $19.2 \%$, while the least found were corals in the form of Coral Mushrooms (Mushroom Coral) with a percentage of $0.4 \%$. Then Site 3 , namely in ANTRA Sario obtained from coral reefs is included in the bad category, with the percentage of live coral cover (Hard Coral) only $7.1 \%$. Coral Diversity in the three survey stations is different. Of the three stations determined above the Tugu Boboca Malalayang site with an index value of 2.54, followed at site 2 namely the Malalayang gas station with an index value of 2.36 and the lowest at site 3 at ANTRA Sario with an index value of 1.33. Furthermore, oceanographic conditions in the Gulf of Manado region are seen in the receding period, most of the air moves westward at the beginning of the period, then moves northeastward in the next period. While in the tide period the water moves northward, starting the period and then it is seen moving northeast and at the end of the period, the east direction.
\end{abstract}

Key words: Coral reef, Oceanographic condition

\begin{abstract}
ABSTRAK
Tujuan penelitian ini adalah menginvestigasi kondisi ekologi ekosistem mangrove di Teluk Manado dan menganalisa kesesuaian lahan ekosistem mangrove sebagai kawasan destinasi wisata baru, mengkaji kondisi oseanografi dikawasan Teluk Manado, Mendapatkan data perkembangan ekosistem terumbu karang untuk dapat dibuatkan terumbu karang buatan dan menghasilkan area mangrove dan terumbu karang buatan sebagai suatu destinasi wisata baru. Penelitian ini dilaksanakan pada bulan April - September 2019 dengan lokasi Teluk Manado dan lokasi survey ekosistem terumbu karang Teluk Manado di tetapkan 3 titik sampel, yang meliputi 3 titik yaitu Depan Tugu BOBOCA Malalayang, Depan SPBU Malalayang dan ANTRA Sario. Pengambilan data terumbu karang yaitu dengan menggunakan metode Line Intercept Transect (LIT). Pengamatan LIT dilakukan dengan
\end{abstract}


SCUBA diving pada kedalaman $6 \mathrm{~m}$. Pengamatan dilakukan dengan cara mencatat bentuk pertumbuhan hidup (lifeform) karang yang ditemukan sepanjang garis transek, dan menghitung presentase penutupannya. Data yang diambil adalah persentase tutupan karang mati, karang hidup, dan jenis lifeform, indeks keragaman yang diambil pada 3 titik sampel. Dari hasil pengamatan dilapangan ditemukan Pada Site 2 (Depan SPBU Malalayang) kondisi terumbu karang termasuk dalam kategori baik, dengan persentase tutupan karang hidup (Hard Coral) sebesar $55 \%$. Pada stasiun ini ditemukan berbagai macam bentuk pertumbuhan karang, namum yang paling tinggi di stasiun ini adalah bentuk pertumbuhan Coral Masive (CM) sebesar 19,2\%, sedangkan yang paling sedikit ditemukan adalah karang dengan bentuk Coral Mushroom (Karang Jamur) dengan persentase $0.4 \%$. Kemudian Site 3 yaitu di ANTRA Sario didapatkan kondisi terumbu karang termasuk dalam kategori buruk, dengan persentase tutupan karang hidup (Hard Coral) hanya 7.1\%. Keanekaragaman Karang di tiga stasiun survey berbeda-beda. Dari ketiga stasiun yang sudah ditetapkan keanekaragaman karang tertinggi ada pada site Tugu Boboca Malalayang dengan nilai indeks sebesar 2,54, diikuti pada site 2 yaitu Depan SPBU Malalayang dengan nilai indeks 2.36 dan paling rendah terdapat pada site 3 di ANTRA Sario dengan nilai indeks 1.33. Selanjutnya kondisi oseanografi pada kawasan teluk manado terlihat bahwa pada periode surut, sebagian besar air bergerak ke arah barat pada awal periode, kemudian bergerak ke arah timur laut pada sisa periode. Sedangkan pada periode pasang air bergerak ke arah utara diawal periode kemudian terlihat bergerak kearah timur laut dan pada akhir period eke arah timur.

Kata Kunci : Terumbu Karang, Kondisi Oseanografi

Article History:

Received November, 152019 Accepted: November 20, 2019 Published: November 25, 2019 


\section{Pendahuluan}

Terumbu karang adalah stukrur bawah air yang tersusun dari endapan kalsium karbonat $\left(\mathrm{CaCO}_{3}\right)$, yang dihasilkan oleh fauna karang yang pada umumnya dijumpai di perairan tropis (Razak dan Simatupang, 2005). Menurut Veron (1986), terumbu karang masuk dalam filum Cnidaria, kelas Anthozoa, ordo Scleractinia dan memiliki 15 famili. Adapula faktor-faktor fisika dan ekologi yang menjadi pembatas kehidupan terumbu karang yaitu suhu, salinitas, cahaya, sedimentasi, gelombang dan kedalaman. Faktor ekologi yaitu persaingan, pemangsaan dan grazing (Nybakken, 1992). Di daerah terumbu karang hidup organisme yang berasosiasi yaitu Alga, Krustasea, Moluska, Ekinodermata dan Ikan (Nontji, 2002). Menurut Romimohtarto dan Juwana (2007), terumbu karang merupakan ekosistem yang subur dan kaya akan makanan. Struktur fisiknya yang rumit, bercabang-cabang, berguagua dan berlorong-lorong membuat ekosistem ini habitatnya sangat menarik bagi banyak jenis biota laut baik flora maupun fauna.

\section{Pengembangan pariwisata} merupakan salah satu cara dalam pengembangan suatu kawasan atau daerah. Pengembangan pariwisata ini tidak terlepas dari keberadaan sumber daya alam maupun sumber daya buatan sebagai potensi daerah yang dimiliki suatu daerah atau kawasan. Potensi daerah tersebut merupakan salah satu sumber aset wisata yang diunggulkan baik berupa keindahan alam, peninggalan budaya masa lampau (wisata budaya) maupun dari komoditas unggulan yang khas daerahnya.

Pariwisata berkelanjutan adalah pariwisata yang memenuhi kebutuhan wisatawan dan masyarakat lokal sekaligus melindungi dan meningkatkan kesempatan untuk generasi masa depan. Pengelolaan seluruh sumber daya dilakukan sedemikian rupa sehingga kebutuhan ekonomi, sosial, dan estetika dapat terpenuhi dengan tetap menjaga integritas budaya, proses ekologi, keanekaragaman hayati, dan sistem pendukung kehidupan.

Minimnya ketersediaan data tentang ekosistem terumbu karang yang mengambarkan kondisi terumbu karang hingga titik-titik geografis terumbu karang di Teluk Manado, membuat kami terdorong untuk melakukan survey pendataan ekosistem terumbu karang di teluk manado, data yang dihasilkan, diharapkan bisa memberi gambaran kondisi terumbu karang di Teluk Manado, memberi informasi titik-titik geografis letak terumbu karang, dan 
bisa di jadikan bahan pertimbangan untuk pengembangan ekosistem terumbu karang. Selain itu mengkaji tentang kondisi oseanografi dikawasan Teluk Manado yang akan menjadi datadata penunjang dalam pertimbangan untuk menghasilkan area mangrove dan terumbu karang buatan sebagai suatu destinasi wisata baru.

\section{Metode Penelitian}

\subsection{Lokasi survey}

Lokasi survey ekosistem

Terumbu Karang Teluk Manado di tetapkan 3 titik sampel, yaitu didepan Tugu Boboca Malalayang, didepan SPBU Malalayang, dan di sekitar Sekretariat Asosiasi Nelayan Tradisional (ANTRA) Sario.

\subsection{Prosedur Penelitian.}

Pengambilan data terumbu karang mengacu pada English et al (1994) yaitu dengan menggunakan metode Line Intercept Transect (LIT), metode ini merupakan teknik yang dikembangkan dalam ekologi tumbuhan terrestrial dan diterapkan dalam ekologi terumbu karang. Pengamatan LIT dilakukan dengan SCUBA diving pada kedalaman $6 \mathrm{~m}$ (English et al, 1994). Dengan asumsi bahwa dua kedalaman tersebut juga masih mendapat penetrasi cahaya matahari yang paling besar (Nybakken, 1992). Pengamatan dilakukan dengan cara mencatat bentuk pertumbuhan hidup (lifeform) (Tabel 2) karang yang ditemukan sepanjang garis transek, dan menghitung presentase penutupannya.

Tabel 2. Bentuk Pertumbuhan hidup (Lifeform)

\begin{tabular}{|l|l|l|}
\hline Kode & \multicolumn{1}{|c|}{ Kategori } & \multicolumn{1}{c|}{ Keterangan } \\
\hline ACB & Acropora Branching & Percabangan $\pm 2^{\circ}$ \\
\hline ACE & Acropora Encrusting & $\begin{array}{l}\text { Biasanya berupa pelat dasar dari bentuk Acropora } \\
\text { yang belum dewasa }\end{array}$ \\
\hline ACS & Acropora Submassive & Kokoh berbentuk bonggol atau baji \\
\hline ACD & Acropora Digitate & Percabangan tidak sampai $2^{\circ}$ \\
\hline ACT & Acropota Tabulate & Pelat mendatar seperti meja \\
\hline CB & Coral Branching & \\
\hline CE & Coral Encrusting & Karang menempel pada satu atau lebih titik, bentuk \\
\hline CF & Coral Foliose & Benyerupai daun \\
\hline CM & Coral Massive & Berbentuk bola atau batu besar atau tanggul \\
\hline CS & Coral Submassive & Soliter \\
\hline CMR & Coral Mushroom & Karang api \\
\hline CME & Coral Millepora & Karang Biru, Soliter \\
\hline CHL & Coral Heliopora & $\begin{array}{l}\text { Kerang dengan rangka keras seperti tabung tersusun } \\
\text { bertingkat dan berwarna merah }\end{array}$ \\
\hline CTU & Tubipora & Baru saja mati, warna putih hingga putih kotor \\
\hline DC & Karang Mati & Warna tidak putih telah ditumbuhi alga \\
\hline DCA & Karang mati denga alga & \\
\hline & Fauna lain: & Karang berbentuk lunak \\
\hline SC & Soft Coral &
\end{tabular}




\begin{tabular}{|c|c|c|}
\hline $\mathrm{SP}$ & Sponge & $\begin{array}{l}\text { Kelompok hewan tubuh berpori-pori, koloni lunak } \\
\text { dengan rangka spikula }\end{array}$ \\
\hline $\mathrm{ZO}$ & Zoanthids & Cnidaria \\
\hline OT & Others & $\begin{array}{l}\text { Biota lainnya yang berassosiasi dengan terumbu } \\
\text { seperti, Ascidians, anemon, gorgonian, kima raksasa, } \\
\text { timun laut, bulu babi, dll }\end{array}$ \\
\hline $\mathrm{AA}$ & Alga Assemblage & $\begin{array}{l}\text { Kelompok makro algae sejenis, dalam jumlah cukup } \\
\text { banyak }\end{array}$ \\
\hline $\mathrm{CA}$ & Coralline Algae & $\begin{array}{l}\text { Kelompok alga dengan bentuk hidup meraya/ } \\
\text { mengerak dan menghasilkan kapur }\end{array}$ \\
\hline $\mathrm{HA}$ & Halimeda & $\begin{array}{l}\text { Kelompok makro alga dengan talus tersusun } \\
\text { bertingkat dan mengandung kapur }\end{array}$ \\
\hline MA & Macroalgae & Kelompok makro algae hijau, coklat dan merah \\
\hline TA & Tuft algae & $\begin{array}{l}\text { Kelompok makro algae bentuk benang/ filament dan } \\
\text { kelihatan seperti lumut }\end{array}$ \\
\hline $\mathrm{S}$ & Sand & Pasir \\
\hline $\mathrm{R}$ & Rubble & Pecahan karang tak beraturan \\
\hline SI & Silt & Butiran partikel lebih halus \\
\hline RK & Rock & Batuan beku, cadas \\
\hline WA & Water & Kolom air lebih dari $50 \mathrm{~cm}$ \\
\hline
\end{tabular}

\subsection{Analisis Data}

Besar persentase tutupan karang mati, karang hidup, dan jenis lifeform lainnya dihitung dengan rumus (English Et Al., 1997 dalam Lalamentik).

$$
C=\frac{a}{A} \times 100 \%
$$

Ket :

$\mathrm{C}=$ Persentase tutupan lifeform $i$

$\mathrm{a}=$ Panjang transek lifeform $i$

$A=$ Panjang total transek

Kriteria penelian kondisi terumbu karang adalah berdasarkan persentase tutupan karang hidup (kep MENHL No 4 tahun 2001) dengan kategori sebagai berikut

1. Karang Buruk $=0-24,9 \%$

2. Karang Sedang $=25-49,9 \%$

3. Karang Baik $=50-74,9 \%$

4. Karang Sangat Baik $=75-100 \%$

\subsection{Indeks Keragaman}

Indeks Keragaman ( $\left.H^{\prime}\right)$ menggambarkan keadaan populasi organisme jumlah individu masing-masing jenis dalam suatu komunitas. Rumus indeks keragaman menurut Shanon-Wiener dalam Krebs 1972) adalah sebagai berikut; $H^{\prime}=$ $\sum_{t=1}^{n}(p i \log p i)$

Keterangan 
H' : Indeks Keragaman Shanon

$\mathrm{Pi} \quad$ : Proporsi bentuk hidup ke-I terhadap total penutupan biota

$\mathrm{n} \quad$ : Jumlah Jenis

Kategori Keragaman biota menurut Shanon-Wiener dalam Krebs (1972) adalah sebagai berikut :

$$
\begin{array}{ll}
\mathrm{H}^{\prime}<1 & =\text { Keragaman Kecil } \\
1 \leq H^{\prime}<3 & =\text { Keragaman Sedang } \\
H^{\prime} \geq 3 & =\text { Keragaman Tinggi. }
\end{array}
$$

\section{Hasil Dan Pembahasan}

\subsection{Lokasi depan Tugu Boboca} Malalayang

Gambaran topografi pada site tuguh boboca malalayang adalah berbentuk datar (Flat). Bila kita melakukan penyelaman dengan cara beach entry, maka kita akan menemukan hamparan subtract berpasir dengan luasan $\pm 200 \mathrm{~m}^{2}$. Selanjutnya kita akan menemukan hamparan terumbu karang yang cukup luas dengan di dominasi oleh karang massive, dan kita akan menjumpai banyak ikan karang serta berbagai biota yang berasosiasi di ekosistem terumbu karang.

Setelah dilakukan pendataan kondisi terumbu karang dan diolah, didapati bahwa dilokasi ini kondisi terumbu karang termasuk dalam kategori sedang, karena persentase tutupan karang hidup (Hard coral) berkisar pada 45.8\% (Gambar 1). Dilokasi ini bentuk pertumbuhan karang massive (CM) adalah bentuk pertumbuhan karang yang tertinggi pada kisaran 17,8\% (Gambar 2).

\subsection{Lokasi di Depan SPBU}

Malalayang

Pada Site 2 didapatkan kondisi terumbu karang termasuk dalam kategori baik, dengan persentase tutupan karang hidup (Hard Coral) sebesar 55\% (Gambar 4). Pada stasiun ini ditemukan berbagai macam bentuk pertumbuhan karang, namum yang paling tinggi di stasiun ini adalah bentuk pertumbuhan Coral Masive (CM) sebesar $19,2 \%$, sedangkan yang paling sedikit ditemukan adalah karang dengan bentuk Coral Mushroom (Karang Jamur) dengan persentase 0.4\% (Gambar 5).

Ada beberapa genus karang (Gambar 6) yang terdata dan bisa di identifikasi di lokasi ini, seperti Astreopora, Acropora, Stylophora, Plerogyra, Symphyllia, Pocillopora, Goniastrea, Porites, Fungia, Favites, Goniopora, Leptoseris. 


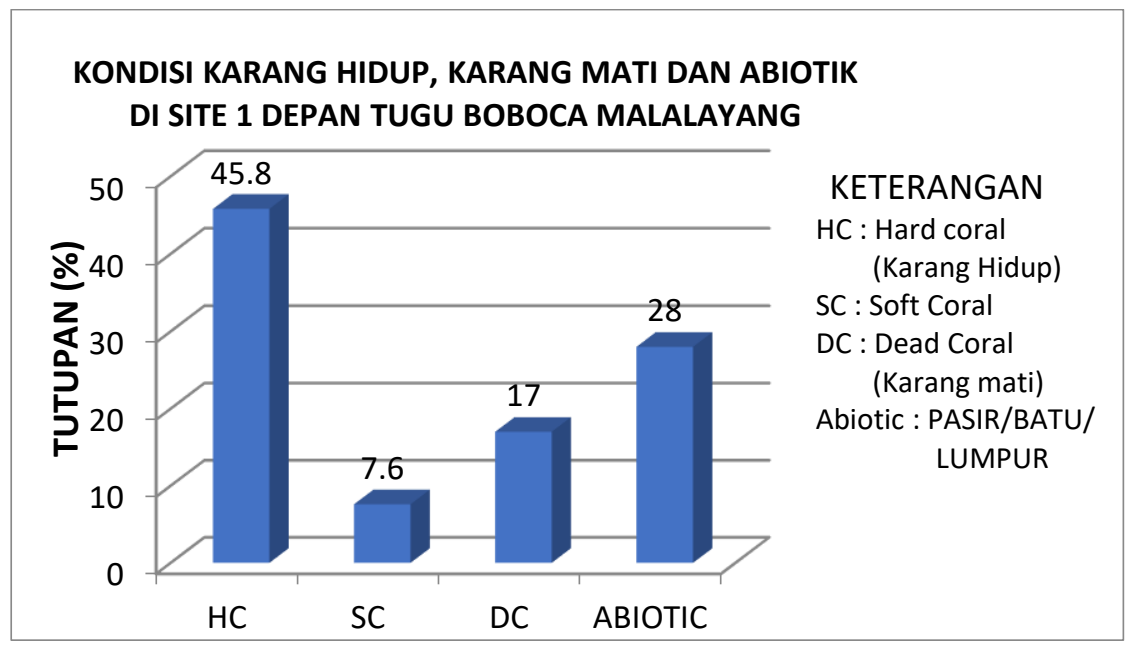

Gambar 1. Kondisi Terumbu karang di site 1 depan Tugu Boboca Malalayang

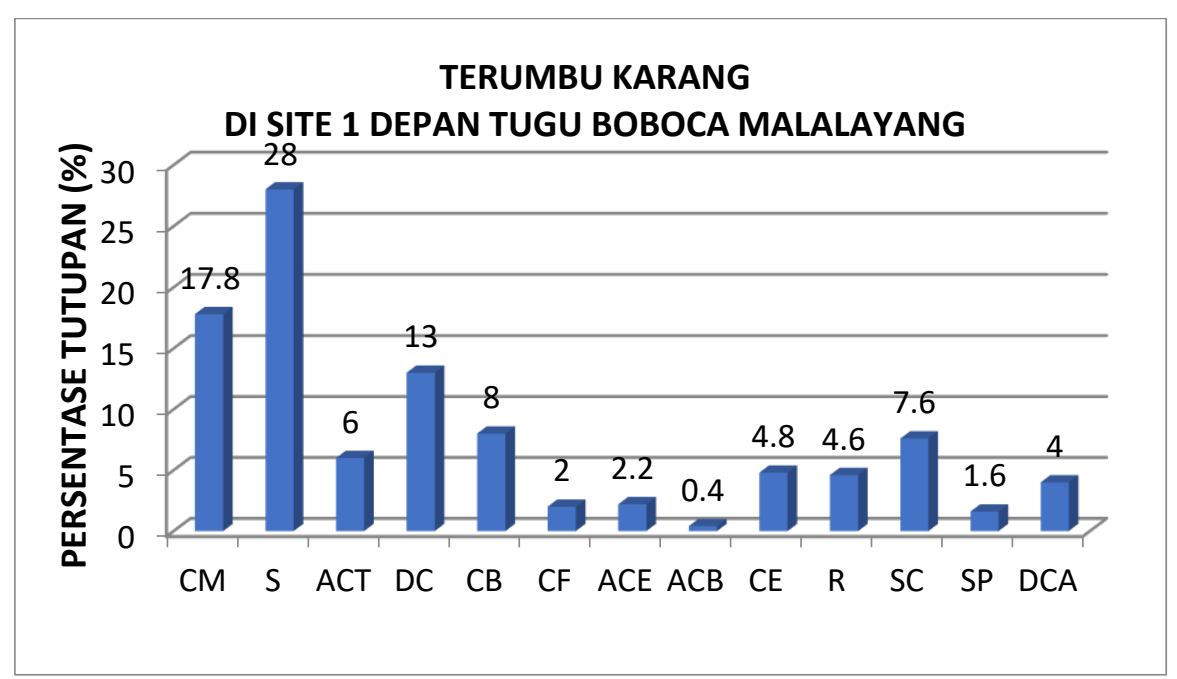

Gambar 2. Persentase tutupan Terumbu Karang di site 1 Depan Tugu Boboca Malalayang 


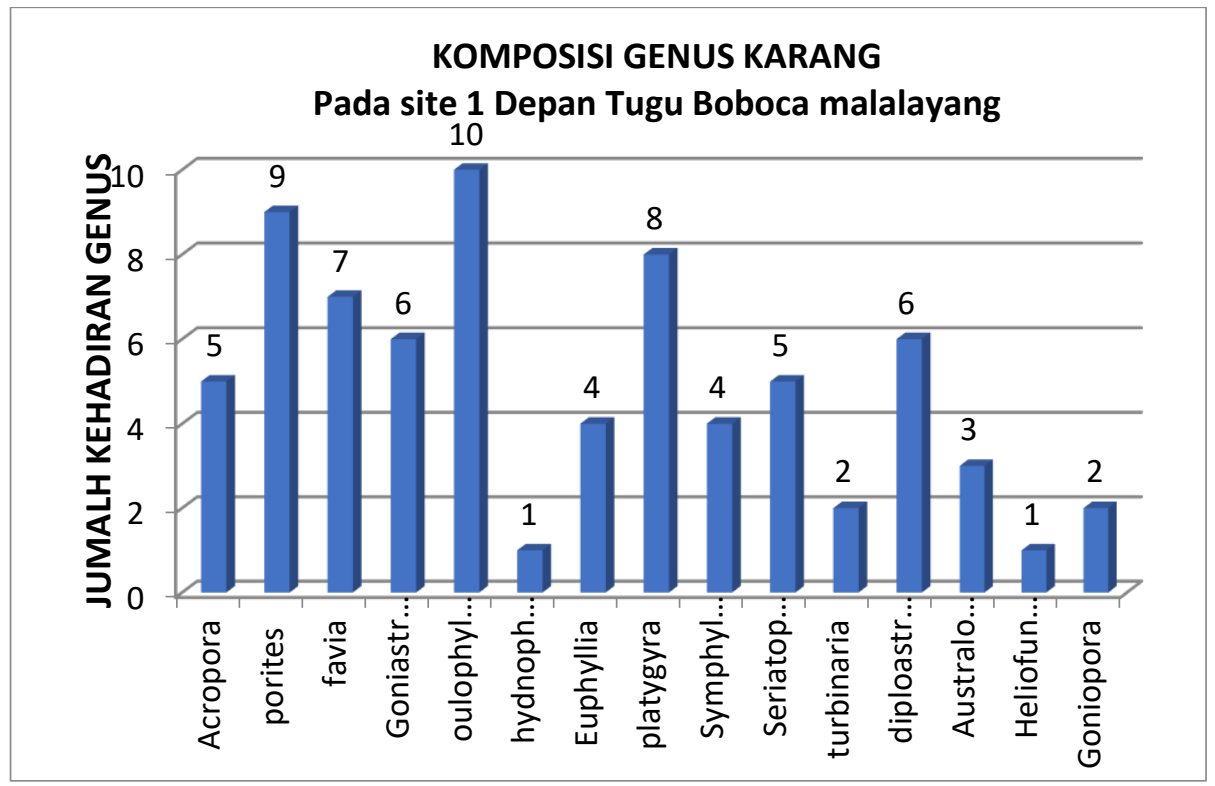

Gambar 3. Komposisi Genus Karang pada site 1 depan Tugu Boboca Malalayang

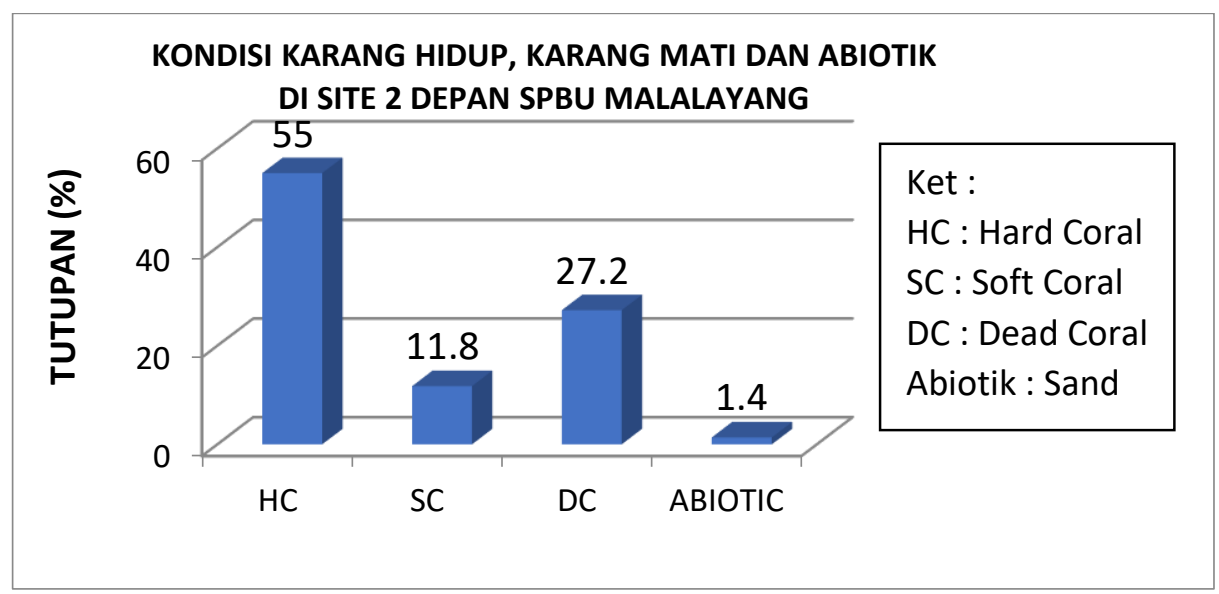

Gambar 4. Kondisi Terumbu karang di site 2 Depan SPBU Malalayang

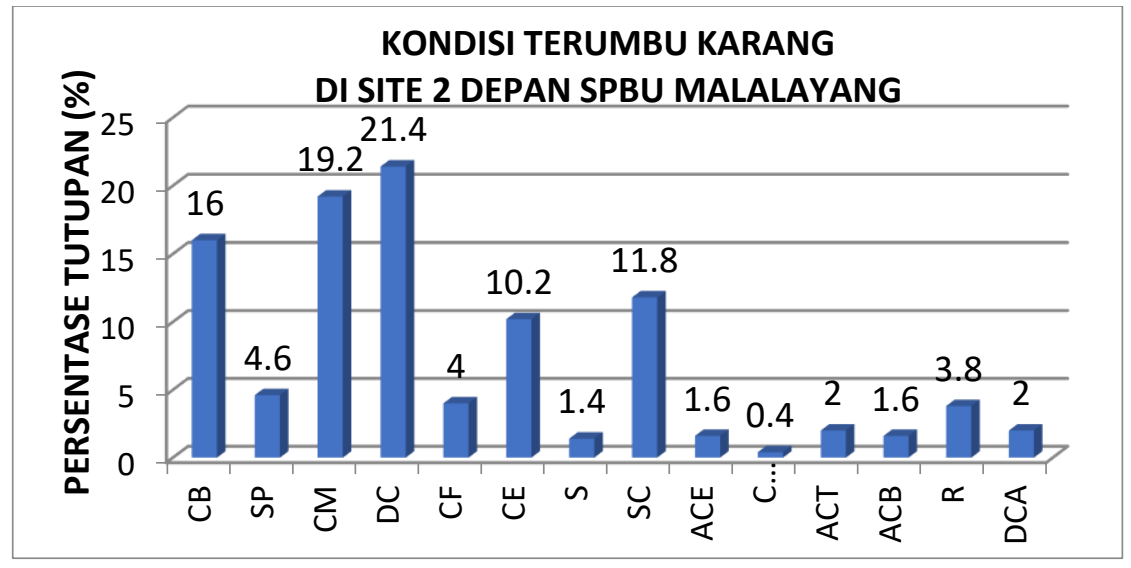

Gambar 5. Persentase tutupan Terumbu Karang di site 2 Depan SPBU Malalayang 


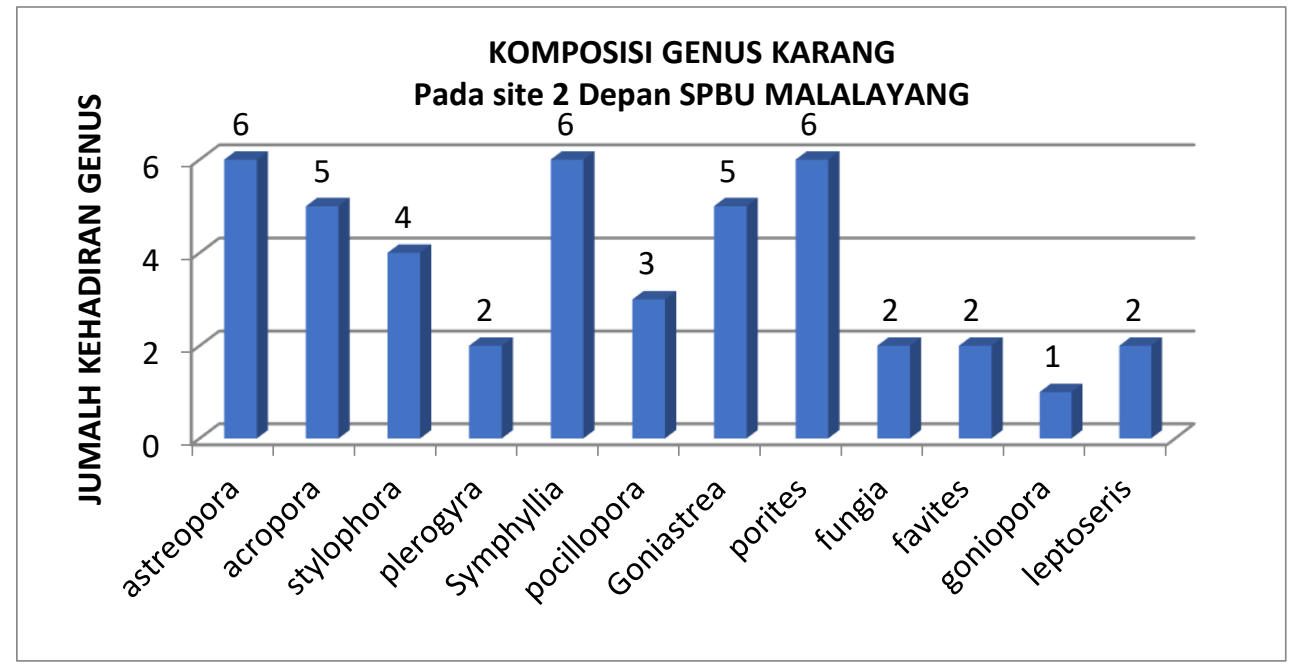

Gambar 6. Komposisi Genus Karang pada site 2 depan SPBU Malalayang

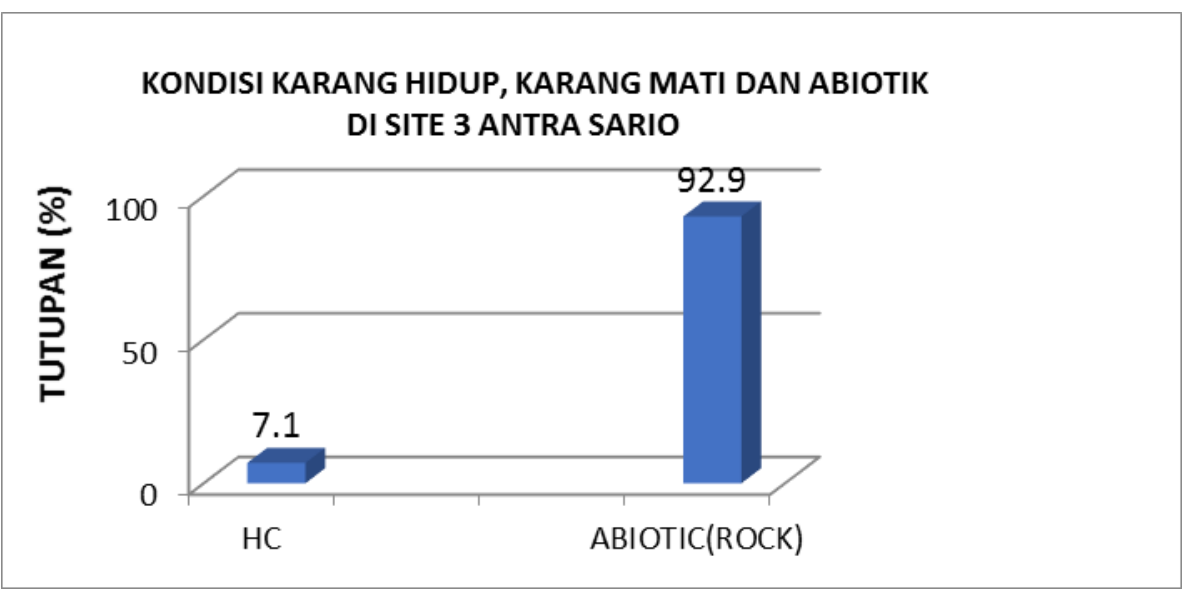

Gambar 7. Kondisi Terumbu karang di site 3 ANTRA Sario

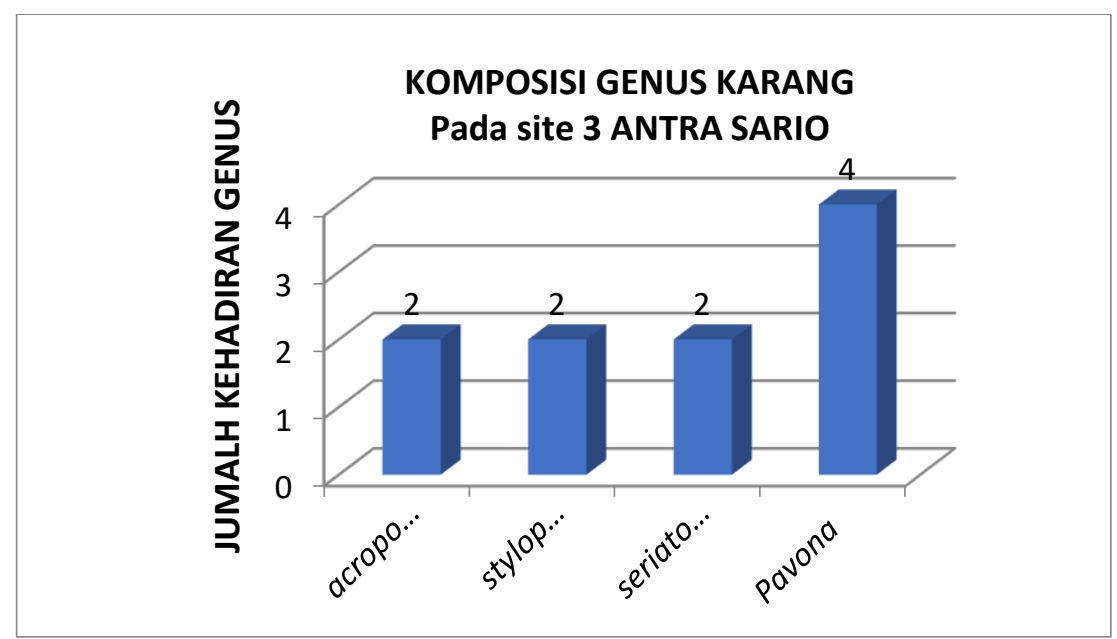

Gambar 8. Komposisi Genus Karang pada site 3 ANTRA Sario 


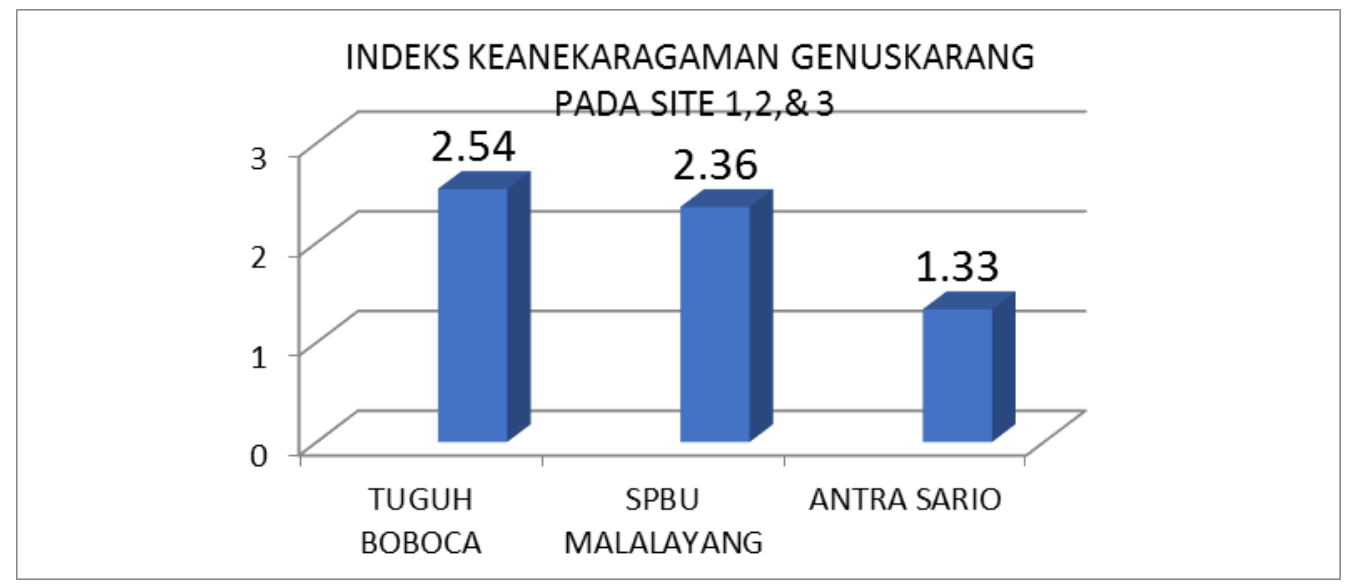

Gambar 9. Indeks Keragaman Genus Karang Pada Site 1, 2, 3

3.3 Lokasi Asosiasi Nelayan

Tradisional (ANTRA) Sario

Pada Site 3 didapatkan kondisi terumbu karang termasuk dalam kategori buruk, dengan persentase tutupan karang hidup (Hard Coral) hanya $7.1 \%$ (Gambar 7 ). Pada stasiun ini komponen abiotik sangat tinggi yaitu sebesar $92.9 \%$, dikarenakan stasiun ini adalah daerah reklamasi, namun disisi lain, batu timbunan reklamasi ini berkontribusi sebagai media atau tempal menempelnya benih-benih karang (Settel). Di Stasiun ini hanya ditemukan karang dengan bentuk pertumbuhan Acropora Tabulate, Karang bercabang/Coral Branching Malalayang dengan nilai indeks sebesar 2,54, diikuti pada site 2 dengan nilai indeks 2.36 dan paling
(CB) dan Coral Encrusting (CE) (Gambar 8).

Dikarenakan perensetase tutupan yang termasuk dalam kategori buruk, distasiun ini hanya ditemukan beberapa genus karang (Gambar 9) yang teridentifikasi, seperti Acropora, Stylophora, Seriatopo dan Pavona.

\subsection{Keanekaragam Karang \\ Keanekaragaman Karang di tiga} stasiun survey berbeda-beda. Dari ketiga stasiun yang sudah ditetapkan keanekaragaman karang tertinggi ada pada site Tugu Boboca

rendah terdapat pada site 3 dengan nilai indeks 1.33. 
3.5. Kondisi Oseanografi

Pola Arus

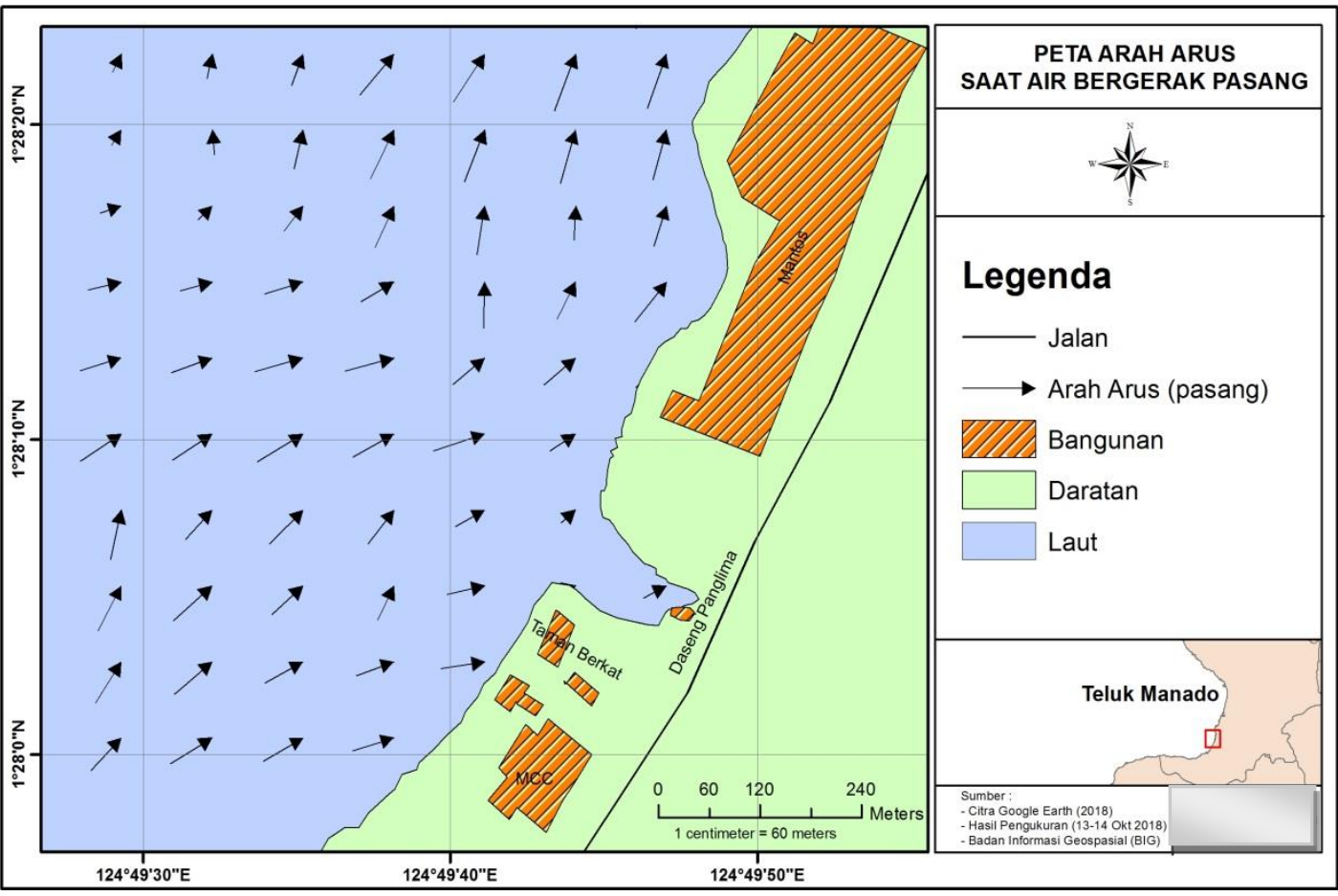

Gambar 10. Arah Arus Pada Saat Pasang

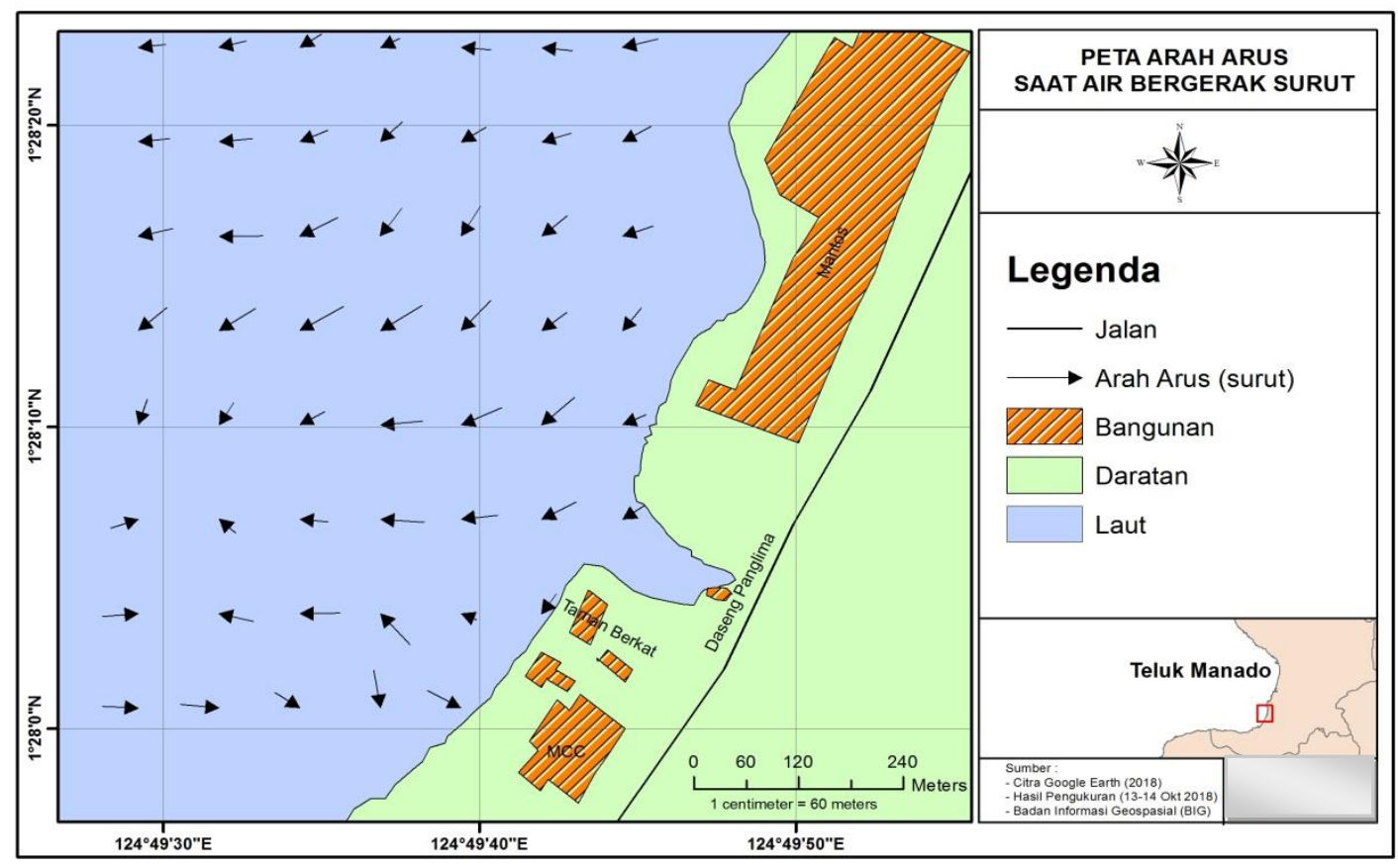

Gambar 11. Arah Arus Pada Saat Surut 
Kecepatan Arus

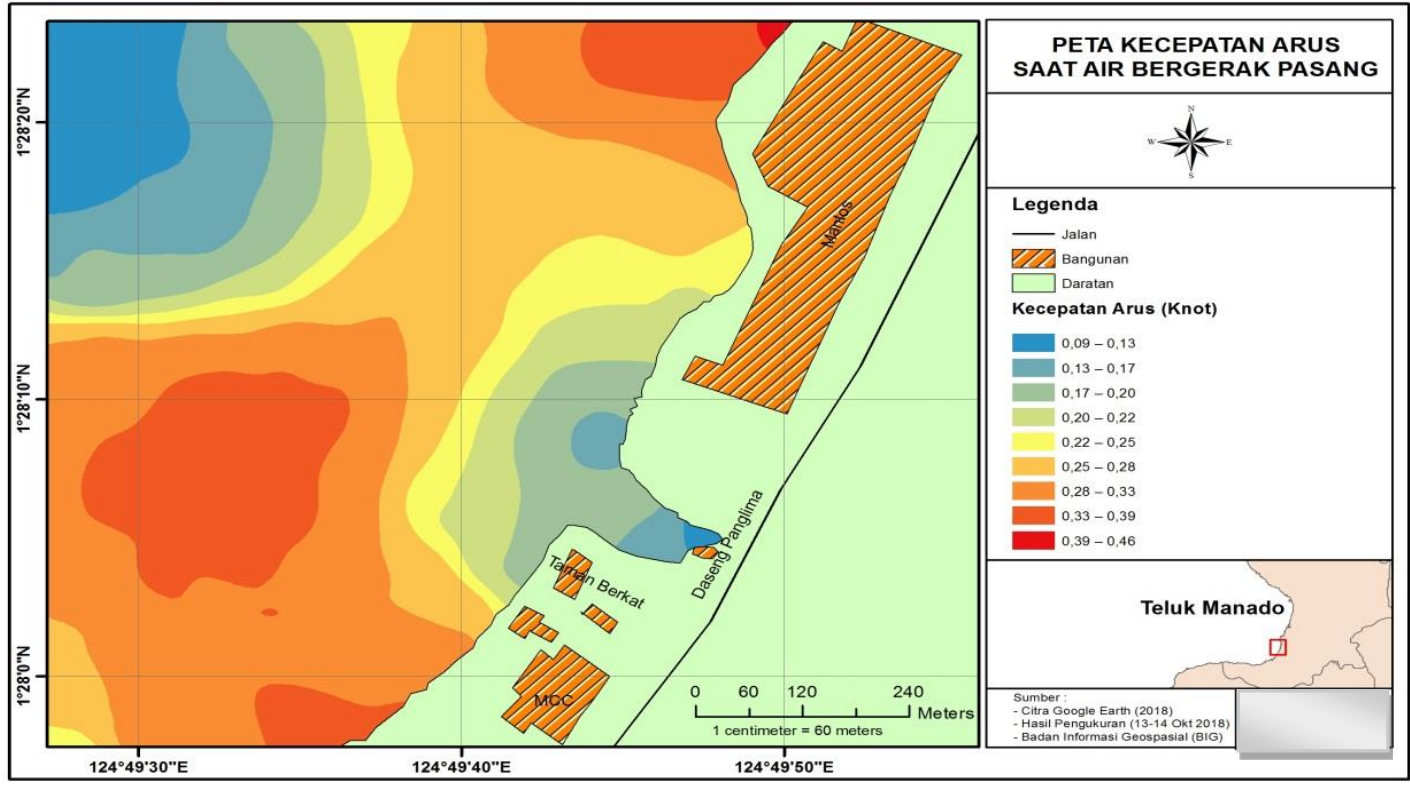

Gambar 12. Kecepatan Arus Pada Saat Pasang

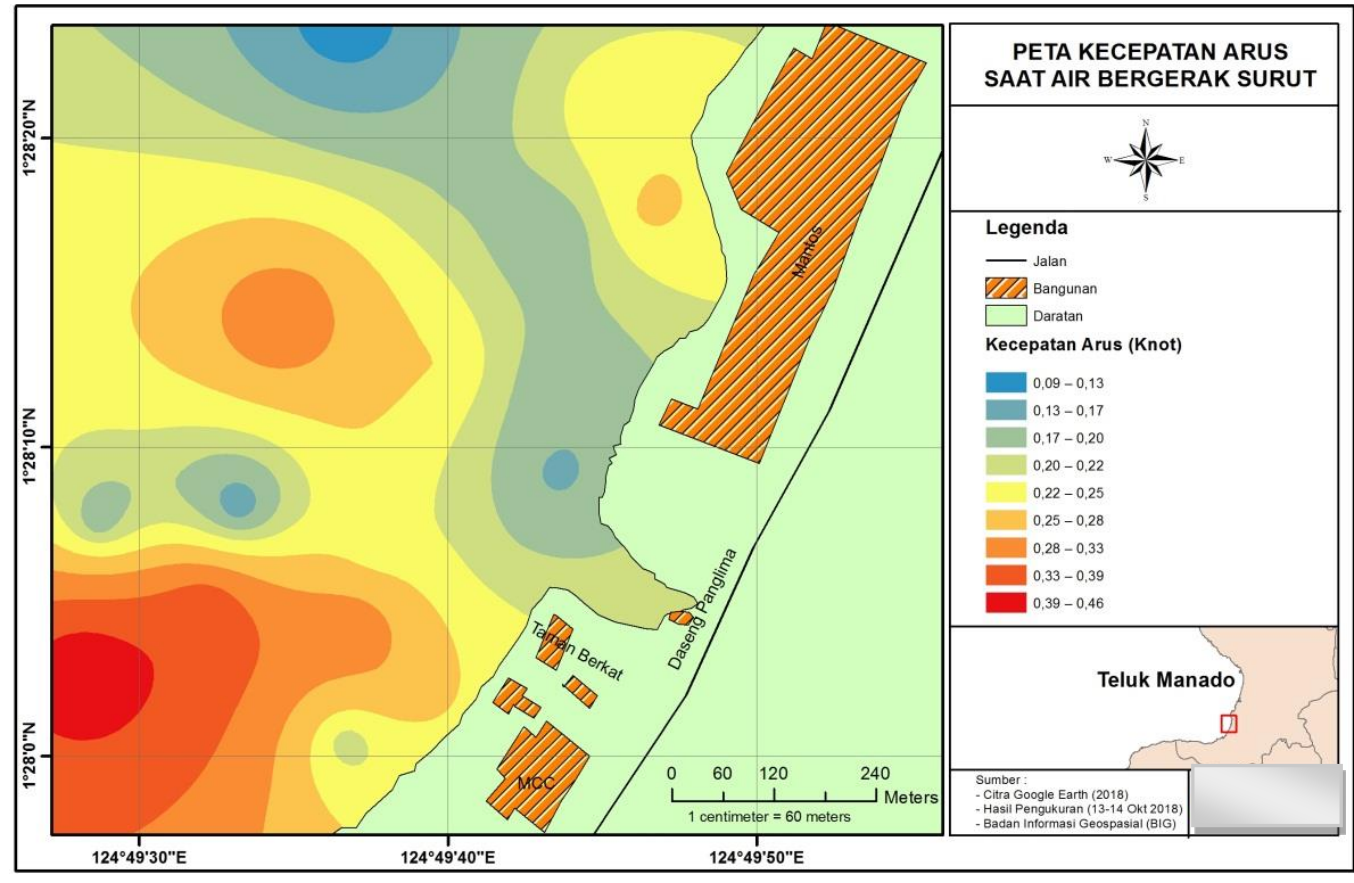

Gambar 13. Kecepatan Arus Pada Saat Surut 
Kondisi oseanografi pada teluk Manado terlihat bahwa Pada periode surut, sebagian besar air bergerak ke arah barat pada awal periode, kemudian bergerak ke arah timur laut pada sisa periode. Sedangkan pada periode pasang air bergerak ke arah utara diawal periode kemudian terlihat bergerak ke arah timur laut dan pada akhir period ke arah timur. Secara umum, pola pergerakan massa air cenderung searah garis pantai, kecuali di tempat yang sangat dekat muara pergerakan cenderung chaotic.

\section{KESIMPULAN}

1. Pada Site 2 (Depan SPBU Malalayang) kondisi terumbu karang termasuk dalam kategori baik, dengan persentase tutupan karang hidup (Hard Coral) sebesar 55\%. Pada stasiun ini ditemukan berbagai macam bentuk pertumbuhan karang, namum yang paling tinggi di stasiun ini adalah bentuk pertumbuhan Coral Masive (CM) sebesar 19,2\%, sedangkan yang paling sedikit ditemukan adalah karang dengan bentuk Coral Mushroom (Karang Jamur) dengan persentase $0.4 \%$.

2. Kemudian Site 3 yaitu di ANTRA Sario didapatkan kondisi terumbu karang termasuk dalam kategori buruk, dengan persentase tutupan karang hidup (Hard Coral)

hanya $7.1 \%$. Keanekaragaman Karang di tiga stasiun survey berbeda-beda.

3. Dari ketiga stasiun yang sudah ditetapkan keanekaragaman karang tertinggi ada pada site Tugu Boboca Malalayang dengan nilai indeks sebesar 2,54, diikuti pada site 2 yaitu Depan SPBU Malalayang dengan nilai indeks 2.36 dan paling rendah terdapat pada site 3 di ANTRA Sario dengan nilai indeks 1.33.

4. Selanjutnya kondisi oseanografi pada kawasan teluk manado terlihat bahwa pada periode surut, sebagian besar air bergerak ke arah barat pada awal periode, kemudian bergerak ke arah timur laut pada sisa periode. Sedangkan pada periode pasang air bergerak kearah utara diawal periode kemudian terlihat bergerak kearah timur laut dan pada akhir periode ke arah timur.

5. Berdasarkan pengamatan kondisi terumbu karang dikaitkan dengan kondisi oseanografi di kawasan Teluk Manado maka ekosistem terumbu karang yang ada di kawasan Teluk Manado sesuai untuk dijadikan kawasan destinasi wisata baru. Dengan mengkombinasikan data ini dapat ditentukan struktur untuk terumbu karang buatan sebagai suatu destinasi wisata baru 
DAFTAR PUSTAKA

CRITC-COREMAPII-LIPI. 2006. Bintan Baseline Ekologi. CRITIC-LIPI. Jakarta. Dalam Try Febrianto

English, et, al., 1994. Survey Manual for Tropical Marine Resources. Australian Institute of Marine Science., Townsville. Australia

Krebs, C. J., 1972. Ecology, The Experimental Analisys of Distribution and Abundance. Haper and Row Publication. New York.

Nontji A., 2002. Laut Nusantara. Djambatan, Jakarta. 367 hal.

Nybakken, J. (1992). Biologi Laut : 644 pp.R
Terjemahan Marine Biology : An Ecological Approach, Oleh Eidman, M., Jutomo. Jakarta: Gramedia.

Razak, T, B dan Simatupang, K. L. M. A., 2005. Buku Panduan Pelestarian Terumbu Karang; Selamatkan Terumbu Karang Indonesia. Yayasan Terangi, Jakarta, 113 hal.

Romimohtarto, K, Juwana, S. 2007.Biologi Laut: IImu Pengetahuan Tentang Biota Laut. PenerbitvDjambatan, Jakarta. Ed. Rev.,cet. Ke-3. Hal. $321-332$.

Veron, J. E. N., 1986, Corals of Australia and the Indo - Pacific. August -Robertson. Publisher, 